(FNRS) and grant no 1830 from the Fondation pour Recherches Médicales Carlos et Elsie De Reuter.

1 Reynolds H. Bronchoalveolar lavage. Am Rev Respir Dis 1987; 135:250-63.

2 Jolliet Ph, Chevrolet JC. Bronchoscopy in the intensive care unit. Intensive Care Med 1992;18:160-9.

3 Suter P, Suter S, Girardin E, Roux-Lombard P, Grau GE, Dayer JM. High bronchoalveolar levels of tumor necrosis factor and its inhibitors, interleukin-1, interferon and elastase in patients with adult respiratory distress syndrome after trauma, shock or sepsis. Am Rev Respir Dis 1992;145: 1016-22.

4 Torres A, Puig de la Bellacasa J, Xobet A. Diagnostic value of quantitative cultures of bronchoalveolar lavage and telescoping plugged catheters in mechanically ventilated patients with bacterial pneumonia. Am Rev Respir Dis 1989; 140:306-10.

5 Steinberg KP, Mitchell DR, Maunder RJ, Milberg JA, Whitcomb ME, Hudson LD. Safety of bronchoalveolar lavage in patients with adult respiratory distress syndrome. $A m$ Rev Respir Dis 1993;148:556-61.

6 Lindholm C, Ollman B. Cardiorespiratory effects of flexible fiberoptic bronchoscopy in critically ill patients. Chest 1978; 74:362-7.

7 Trouillet JL, Guiget $M$. Fiberoptic bronchoscopy in ventilated patients. Evaluation of cardiopulmonary risk under mipatients. Evaluation of cardiopulmonary

8 Baldwin DR, Wise R, Andrews JM, Honeybourne D. Microlavage: a technique for determining the volume of epithelial lining fluid. Thorax 1991;46:658-62.

9 Burns D, Shure D, Moser K. The physiologic consequences of saline lobar lavage in healthy human adults. Am Rev Respir Dis 1983;127:695-701.

\title{
Adventitia
}

\section{The "Cochrane Collaboration"}

The current publicity given to the "Cochrane Collaboration" calls attention to the many contributions made by the late Archie Cochrane to the medical and scientific communities. He and Bradford Hill were the early proponents of the randomised clinical trial. Both cogently argued for its adoption at a time when the inclusion of controls or referents in clinical trials was almost unknown in North America. The idea of a series of centres reviewing various clinical trials and finding whether their design was acceptable and the results valid would probably have been received by Archie with lukewarm enthusiasm. Those who knew him feel that, although he would endorse the need to analyse the data included in such trials, with few exceptions he would have found the task burdensome and mundane.

Unlike most of the participants in the Cochrane Collaboration, Archie was a "shoe leather" epidemiologist who went out and about. He and Ian Higgins stomped all over the Rhondda Fach, visiting house after house, pleading for participation so that they could administer his questionnaire, perform or supervise spirometric tests, and take over 2000 ECG tracings in homes or village halls. They performed similar feats in Stavely, Derbyshire where they interviewed steel workers, coal miners and those who worked for chemical companies, mostly in Derbyshire drizzle and heavy air pollution. Those passing through Stavely in the 1950 s, while realising that it was not the end of the world, certainly thought they could see off the edge!

Archie did not take himself too seriously and was singularly unimpressed by the medical establishment. While he held the Chair of Tuberculosis in Cardiff he tried to persuade the local cardiologists to carry out a clinical trial involving the treatment of myocardial infarction at home and in hospital. His suggestion was rejected somewhat vehemently, but somehow Archie managed to persuade a cardiologist in Bristol to go along with the idea and subsequently he presented his findings to the British Heart Association. He told the audience that those who were treated in hospital had a slightly, but not significantly, better survival rate than those who were treated at home. This prompted a member of the audience to tell him that the trial was unethical and may have led to unnecessary deaths since it was obvious that all patients with a myocardial infarction should be admitted to hospital. Archie then announced, with typical Cochrane panache, that he had deliberately interchanged the results and that those who had been treated at home had done slightly, but not significantly, better. His prior interrogator was then asked whether this meant that the admission to hospital of any patient with a myocardial infarction constituted negligence.

At about the same time Ian Higgins presented his data on the interpretation of over 2000 ECGs performed on the inhabitants of the Rhondda Fach. He pointed out that, with one interpretation around $25 \%$ of the ECGs were abnormal, but if two interpreters were used and there had to be agreement, the number of abnormal ECGs fell to $16 \%$. Increasing the number of interpreters led to fewer and fewer ECGs being agreed as abnormal until with seven or eight readers all the ECGs would have been interpreted as normal. This led to the formulation of Higgins' Law: "The apparent frequency of any condition is inversely proportional to the number of investigators (or investigations) required to establish its frequency."

I suspect Archie would feel that the Cochrane Collaborators who stay in their office and analyse the various studies are somewhat akin to Sassoon's "Scarlet Majors at the Base who speed glum heroes up the line, if not to death" but to endless tedium. 